\title{
A retórica do trágico em o remorso de baltazar serapião
}

\author{
The rhetoric of the tragic in o remorso de baltazar serapião
}

\author{
Aurora Gedra Ruiz Alvarez \\ Universidade Presbiteriana Mackenzie. São Paulo, SP, Brasil.
} -

\begin{abstract}
Resumo: A partir das elaborações teóricas de Aristóteles sobre a tragédia, discute-se neste estudo o conceito de trágico, tendo como aporte teórico Albin Lesky e Peter Szondi. Para este último, o trágico é compreendido sob o enfoque filosófico que se manifesta em consonância com uma determinada cultura e um certo tempo. À luz deste pressuposto teórico e de contribuições de outros estudiosos sobre esse tema, examina-se como a linguagem, particularmente a antítese e o oximoro, enforma uma percepção de mundo trágica no discurso do protagonista de o remorso de baltazar serapião de Valter Hugo Mãe, que efeitos de sentido esses recursos estilísticos produzem nessa configuração e que olhar sobre si e sobre o mundo a personagem apresenta no romance.
\end{abstract}

Palavras-chave: trágico; o remorso de baltazar serapião; antítese; oximoro.

\begin{abstract}
Based on Aristotle's theoretical views about tragedy, the concept of tragic is discussed in this study, also taking into consideration Albin Lesky's and Peter Szondi's theoretical contributions. The latter understands the tragic under the philosophical approach that it is manifested in consonance with a given culture and a given time. In the light of this theoretical assumption and based on other scholars' considerations about this theme, it is investigated how the language, having as structuring elements the antithesis and the oxymoron, shapes a tragic worldview in the protagonist's speech of the o remorso de baltazar serapião by Valter Hugo Mãe, what effects of meaning these rhetoric resources produce in this configuration and which views about himself and the world the character shows at this novel.
\end{abstract}

Keywords: tragic; o remorso de baltazar serapião; antithesis; oxymoron.

\section{Considerações iniciais}

O trágico, enquanto modo de representação, está associado à tragédia, manifestação dramática que conhece as primeiras reflexões na Poética de Aristóteles. No entanto, a essência desse fenômeno pode ser encontrada em outras formas literárias. Seu princípio constitutivo reside, em geral, no posicionamento do herói diante de duas realidades distintas: a pólis e a psyché. Estas duas realidades em confronto constringem-no a viver momentos de tensão que não apontam saídas. O embate entre a esfera social e a psíquica responde pelo conflito (ágon) que dilacera o homem, biparte-o no crucial impasse entre atender as forças do consenso ou seguir as forças internas, entre o dever ou o querer. A escolha por este último vetor resulta na "falha trágica", ou seja, mostra a dificuldade de o herói reconhecer aquilo que é considerado aceitável pelo seu contexto cultural e expõe uma resistência para admitir a sua deficiência humana (LESKY, 1971, p.23). Esta fragmentação dolorosa (pathos), fruto de experiências angustiantes, encontram-se em Édipo Rei de Sófocles, em Hamlet de William Shakespeare e em muitos outros heróis construídos pela cena dramática. Se o trágico na dramaturgia se apresenta sobre esse viés, questiona-se: como se constitui o trágico no romance? Ele segue os mesmos preceitos da tragédia? Para responder essas perguntas, propomos partir do entendimento de que a tragédia nasce da ação e da linguagem da personagem, conforme nos ensina Aristóteles (2007, p.47), e deste princípio teórico, caminhar para o conceito do trágico, com a contribuição de outros especialistas no assunto. Neste trabalho pretendemos examinar os elementos estilísticos que permeiam o discurso e a ação do herói e gerenciam a construção do trágico em $o$ remorso de baltazar serapião (2010), de Valter Hugo Mãe, enquanto filosofia que alicerça o modo de a personagem ver o mundo. 
Para tanto, delineamos discutir primeiramente o conceito do trágico e, a seguir, iniciaremos a análise do romance, centrando a nossa atenção precipuamente em dois recursos estilísticos dominantes: a antítese e o oximoro, agenciadores do efeito de sentido trágico na narrativa. Observaremos que o discurso de Baltazar, o protagonista, parte de uma situação de aparente equilíbrio, acelera o andamento para um confronto intransponível que se precipita no desfecho trágico.

\section{Breves reflexões sobre o trágico}

Tendo como base as reflexões de Aristóteles sobre a tragédia, Albin Lesky sistematiza os traços constitutivos do trágico, amparado em uma citação de Wolfgang Goethe que afirma: "Todo o trágico se baseia numa contradição inconciliável. Tão logo aparece ou se torna possível uma acomodação, desaparece o trágico" (apud LESKY, 1971, p.25). Deste ponto, Lesky passa a examinar as antinomias que orientam a construção do trágico enquanto conceito filosófico. Nesta linha de raciocínio, ele aponta três requisitos indispensáveis para a materialização desse fenômeno:

a) configura-se "a considerável altura da queda". Nas palavras do teórico, o trágico é "a queda de um mundo ilusório de segurança e de felicidade para o abismo da desgraça iniludível" (LESKY, 1971, p. 26 - grifos do autor).

b) atribui-se o grau do trágico quando ocorre "a possibilidade de relação com o nosso próprio mundo" (LESKY, 1971, p.26). Só nos comove ou nos afeta "quando nos sentimos atingidos nas profundas camadas do nosso ser" (LESKY, 1971, p. 27).

c) o terceiro requisito para a constituição do trágico é a consciência que o herói tem de sua ação trágica e dos infortúnios que dela provêm (LESKY, 1971, p.27).

Notemos que o primeiro componente do trágico, mencionado por Lesky, diz respeito ao andamento da trama, isto é, apreende-se nela uma ruptura entre uma situação de equilíbrio, de felicidade na vida do sujeito da ação trágica, e uma vivência de desgraças; o segundo, situa o enfoque na recepção. Neste caso, o trágico configura-se no texto, creditado pela vivência do leitor. $\mathrm{O}$ terceiro ingrediente focaliza o posicionamento crítico do herói diante da ação; a sua consciência é condimento essencial para a existência da ação trágica.

Convocamos um segundo teórico para iluminar a nossa reflexão sobre o trágico e para o exame do romance em foco. Referimo-nos a Peter Szondi (2004), que faz um percurso que parte de Aristóteles e passa por vários filósofos que se debruçam sobre a questão. Nesta linha de pensamento, Szondi compreende a existência de duas grandes concepções sobre a poética do trágico: uma que se funda nos preceitos de Aristóteles acerca da tragédia e vê essa forma artística como sendo atemporal, isto é, que não se afeta diante das conjunturas histórico-culturais de cada sociedade. Outra, que surge no final do século XVIII, cujo grande expoente é Hegel, que entende o trágico como resultado da dialética entre as linhas de força do contexto sócio-histórico-cultural e as do indivíduo. Deste período em diante até a contemporaneidade, os estudiosos desse assunto (Schelling, Hegel, Nietzche etc.) - Szondi inclusive - buscam compreender o trágico, segundo a percepção filosófica de cada época (SZONDI, 2004, p. 23). Ancorados nesta última formulação teórica, examinaremos no corpus que poética do trágico se figura no discurso do protagonista.

\section{Baltazar Serapião: o conflito identitário e o amoroso}

Cabe aqui uma pequena apresentação de Valter Hugo Mãe antes de examinarmos o conceito de trágico plasmado na obra, escolhida para corpus deste estudo.

Valter Hugo Mãe, português nascido em Angola, escreve para o público infantil, é também poeta, cantor, artista plástico, romancista, dentre suas muitas atividades. Dos romances escritos, analisaremos o remorso de baltazar serapião (2010), publicado em 2007, que pertence à tetralogia das minúsculas, ao lado de: $o$ nosso reino (2004), o apocalipse dos trabalhadores (2008), a máquina de fazer espanhóis $(2010)^{1}$. Segundo o escritor, a abolição das maiúsculas, até mesmo para os substantivos próprios como os nomes das personagens e o seu próprio nome, visa a "agilizar o texto" e aproximar a escrita do ritmo da fala como ele conta à jornalista Maria Leonor Nunes (MÃE apud NUNES, 2015). É possível que esse procedimento seja também motivado pelo desejo de chamar a atenção do público para a sua escrita transgressora. A fábula do romance eleito para exame trata da trágica existência do protagonista Baltazar Serapião, que vive dois grandes conflitos: o primeiro, é o identitário, resultado dos boatos que apregoam que Baltazar e seus irmãos são filhos da vaca Sarga e de seu pai. Em toda a narrativa, a personagem trava uma luta intensa entre o lado bestial, fruto da marginalização, da violência e da coisificação sofridas sob o jugo dos senhores feudais, Dom Afonso e Dona Catarina, e o desejo de ela afirmar a sua humanidade. O segundo grande conflito, relacionado ao primeiro, trata-se do amor que Baltazar dedica à sua

\footnotetext{
Esclarecemos que será adotado o uso das minúsculas nos títulos e nas citações das obras referidas. Nas minhas considerações, será observado o registro conforme as convenções acadêmicas para cada caso.
} 
esposa, Ermesinda, que é conturbado pelo ciúme gerado pela suspeita de que Dom Afonso, que exige a presença da bela jovem todas as manhãs na casa grande, cobre dela favores sexuais. A suspensão da dúvida, que envolve o suposto adultério, ativa em Baltazar um comportamento animalesco que se manifesta mutilando o corpo da mulher amada, tal qual o seu pai faz à sua mãe.

o remorso de baltazar serapião (2010) constrói um mundo de oposições. De um lado, o despotismo feudal, preconceitos, superstições, bruxarias e atrocidades de toda ordem que desumanizam as personagens, em especial, Baltazar e seu pai; de outro, um caso de amor. Este contraponto pungente é criado por recursos retórico-estilísticos que polarizam as tensões, agudizam os sofrimentos e eliminam a possibilidade de o protagonista escapar do desfecho trágico. Aproximemos as lentes desse universo ficcional e examinemos como se compõem no discurso as tensões criadas por esse antagonismo.

Os dois primeiros parágrafos parecem dissociados do que segue no parágrafo seguinte da narrativa. Percorridas algumas páginas, o leitor começa a deslindar que esse introito funciona como breve síntese do drama da família Serapião/Sarga e do posicionamento do herói ao longo da trama, o qual se reafirma no seu final. Esse procedimento responde pelo caráter cíclico da narrativa. O desfecho remete ao início. Nesse epítome compõe-se o cenário sociocultural de silenciamento da voz feminina, de discriminação e de arbitrariedade patriarcal e feudal que o leitor encontrará na narrativa. Vejamos:

a voz das mulheres estava sob a terra, vinha de caldeiras fundas onde só diabo e gente a arder tinham destino. a voz das mulheres, perigosa e burra, estava abaixo de mugido e atitude da nossa vaca, a sarga, como lhe chamávamos.

mal tolerados por quantos disputavam habitação naqueles ermos, batíamos os cascos em grandes trabalhos e estávamos preparados, sem o saber, para desgraças absolutas ao tamanho de bichos desumanos. Tamanho de gado, aparentados de nossa vaca, reunidos em família como pecadores de uma mesma praga. maleita nossa, nós, reunidos em família, haveríamos de nos destituir lentamente de toda a pouca anormalidade (2010, p. 11)

No primeiro parágrafo Baltazar, a personagemnarrador, apresenta a imagem que ele tem do mundo feminino, herdada das formações discursivas de sua comunidade, especialmente de seu pai. A referência à mulher se configura pela metonímia "voz". O discurso traz no seu bojo todos os tons e sobretons do ideário judaico cristão medieval que vê a mulher como aquela que destruiu o homem, que o impediu de viver no paraíso. De acordo com esse quadro de valores, a mulher apresenta-se como traiçoeira, desinteligente, aquém da Sarga, a vaca, e, como punição de seu ato - o pacto que fez com Lúcifer -, ela sofre no inferno.

O foco do discurso muda no parágrafo seguinte. Trata agora da inserção da família Serapião/Sarga na sua comunidade. Em um contexto sociocultural que reduz as personagens à infrahumanidade e zoomorfiza-as, a intolerância passa a reger as relações sociais e a incutir nesse grupo social, principalmente em Baltazar, a premunição, ainda inconsciente, de que o destino será inexorável. Este vaticínio de desgraça futura é marcado pela presença de expressões portadoras desse conteúdo semântico, presentes em: "estávamos preparados, sem o saber, para desgraças absolutas ao tamanho de bichos desumanos", "pecadores de uma mesma praga", "maleita nossa". Diante do que até então está posto no romance, o leitor pode se perguntar se o que desencadeia o infortúnio é a mulher ou o meio em que esse sujeito da enunciação está inscrito? Ou os dois elementos ao mesmo tempo? De pronto o leitor não tem a resposta. Será necessário aguardar $\mathrm{o}$ andamento da narrativa para erigir esse mundo romanesco, embora as bases dele já tenham sido colocadas.

Como dissemos, a ação instala-se na narrativa a partir do terceiro parágrafo. Deste ponto o leitor entra em contato com a história de segregação em que vive a família Serapião/Sarga. Mesmo nesse estado de marginalização, de miserabilidade, parece que a marcha dos acontecimentos flui em um aparente equilíbrio, e, aos poucos, particularmente Baltazar começa a sentir certas alterações que euforizam a sua existência, causam-lhe ansiedade e despertam a esperança de ser feliz. São os efeitos do seu amor a Ermesinda. Tão logo esse sentimento se manifesta, o pedido de casamento se realiza, a autorização dos pais e, sobretudo, de Dom Afonso se consumam. Introduz-se, porém, uma ruptura nessa sequência de eventos alvissareiros que provoca o desequilíbrio no protagonista e cria tensão na narrativa, materializada ora pela antítese, ora pelo oximoro. Serão essas figuras de linguagem que criam o efeito trágico que passaremos a examinar. Como mencionamos anteriormente, há dois conflitos importantes na narrativa: o identitário e o amoroso. No exame do texto, será visto que eles acabam convergindo, se hibridizando, traduzindo um pathos, um sentimento, complexo, indissolúvel, em que não é possível identificar as fronteiras que separam um do outro.

Os fragmentos, transcritos a seguir, inauguram o processo de tensão na narrativa, dialetizando o que Baltazar idealiza (o querer) e o que o mundo se lhe impõe e o seu caráter não aceita (o dever). 
[...] sem condição nem honrarias que me levassem ali refinado ou melhorado, o que faria senão deixar que meu amor se notasse, há tanto fulgurado para o interior de mim e intenso para sair à brancura do seu ser, e lho disse assim, depender de mim será só digna sua pessoa, posta sobre meus braços como anjo que o céu me empresta, e deus terá sobre nós um gosto de ver e ouvir que inventará beleza a partir de nós para retribuir aos outros. Casai comigo formosa, tanto quanto meus olhos um dia poderiam ver (2010, p. 39).

meti-me em casa sem ânimo nem brio. trabalhar de cornos à mostra não era coisa de aguentar, tentava justificar-me à minha mãe, estropiada de tudo na cama onde meu pai a pusera, por ter de constatar a condenação do sexo frágil. as mulheres são frutos podres, como maçãs podres, raios hão de partir eternamente a eva por ter sido mal lavada de intenções. e, quando a ermesinda puser aqui o pé, o primeiro que lhe acontece é ficar com ele torcido duas vezes o da mãe, para não se esquecer nunca mais. sem pio, que deve vir de artimanhas para me iludir, será sem aviso e sem tempo algum que se terá torta para o curandeiro acudir (2010, p. 52).

Os dois excertos oferecem-nos a primeira manifestação de confronto que acolherá muitas outras na arquitetura do trágico. $\mathrm{O}$ primeiro diz respeito ao pedido de casamento que Baltazar faz a Ermesinda, um discurso que nos lembra as cantigas de amor. $\mathrm{O}$ sujeito poético, podemos assim nomeá-lo tal é a carga lírica do texto, vale-se do arcabouço cultural em que se cumpre a vassalagem amorosa. Aqui o amador assemelha se postar em uma posição inferior ao objeto amado ("sem condição nem honrarias que me levassem ali refinado ou melhorado"). Este assujeitamento afetivo refere-se tanto ao modo como vê a mulher amada - superior aos seus olhos -, quanto à pobreza em que a personagem vive. $\mathrm{Na}$ sequência, o discurso trata da contenção amorosa. Assim como nas cantigas de amor, o amador não pode manifestar publicamente a quem dirige os seus sentimentos, Baltazar, a princípio, mostra que persegue esse ritual até o momento do pedido ("há tanto fulgurado para o interior de mim e intenso para sair"). Se quando requesta Ermesinda, ele infringe os princípios das cantigas de amor, o conteúdo semântico da seleção lexical que domina o discurso se encarrega de manter a concepção da mulher amada no plano elevado. Enquanto as imagens "brancura do seu ser" e "anjo que o céu me empresta" atuam como metáforas de pureza e de divinização, os léxicos "formosa” e "deus terá sobre nós um gosto de ver e ouvir que inventará beleza a partir de nós para retribuir aos outros" apontam para o sentido de que é a partir da amada e da conjunção desta com o amador que Deus criará a beleza. Neste passo temos a repercussão de metáforas muito caras às cantigas de amor e à poética clássica e desta última citamos a camoniana. $\mathrm{O}$ poema "De quantas graças tinha a Natureza", de Camões ${ }^{2}$ (1963, p.50), apresenta no primeiro terceto recursos estilísticos que colocam a beleza, a luz dos olhos da amada, acima daquela encontrada na Natureza. Assim dizem os referidos versos:
Mas nos olhos mostrou quanto podia,
E fez deles um sol, onde se apura
A luz mais clara que a do claro dia
(CAMÕES, 1963, p. 50).

Nesta estrofe, a metáfora "sol" sobreleva o sentido de luminosidade dos olhos da amada, enquanto a comparação contida em "a luz [dos olhos da amada é] mais clara que a do claro dia", expressa a ideia de que é na amada que se encontra o conceito mais perfeito de luz. Situação análoga acontece no discurso de Baltazar quando menciona que “[deus] inventará beleza a partir de nós para retribuir aos outros". Este enunciado é portador da ideia de que o casal de amantes, cuja tônica é a mulher amada, representa a matriz da criação divina.

Ainda nessa declaração de amor, introduz-se uma jura: "e lho disse assim, depender de mim será só digna sua pessoa, posta sobre meus braços como anjo que o céu me empresta". Esta promessa de amor expressa o propósito de Baltazar para o presente e para o futuro em relação a Ermesinda. É o que ele deseja e não o que a vida mostra, como veremos na outra citação.

O segundo texto foi tirado do episódio em que Baltazar, atormentado pelo ciúme da suposta relação adúltera entre Ermesinda e Dom Afonso, tenta escalar a janela da sala da casa grande para descobrir o que ocorria nesses encontros. Em meio a esse intento, Teresa Diaba puxa-lhe as calças para fazer amor e ele cai, fazendo um barulho tão grande que chama a atenção do senhor feudal. Este, irado, joga-lhe um alguidar de água e, como reprimenda, não permite o regresso da jovem à sua casa, nem ao trabalho com os queijos. Deste momento em diante, o protagonista planeia vingança, ou conforme justificativa de suas violências, tenciona castigar a jovem esposa para que ela aprenda a ser fiel.

Estendendo o nosso olhar para outra obra que também trata do ciúme, alcançamos Othello (ca.1604/1996) de Shakespeare. Na análise desse drama, Peter Szondi considera que o ciúme instaura uma dialética que, às

\footnotetext{
2 A estrofe citada foi tirada do poema "De quantas graças tinha, a Natureza", composta pelos versos:

De quantas graças tinha, a Natureza/ Fez um belo e riquíssimo tesouro, E com rubis e rosas, neve e ouro,/ Formou sublime e angélica beleza. // Pôs na boca os rubis, e na pureza/ Do belo rosto as rosas, por quem mouro;/ No cabelo o valor do metal louro;/ No peito a neve em que a alma tenho acesa. //

Mas nos olhos mostrou quanto podia,/ E fez deles um sol, onde se apura/ A luz mais clara que a do claro dia.//

Enfim, Senhora, em vossa compostura/ Ela a apurar chegou quanto sabia/ De ouro, rosas, rubis, neve e luz pura" (CAMÕES,1963, p. 50).
} 
vezes, "permite quase de imediato a mudança para o cômico" (2004, p. 103). Semelhante andamento encontra-se nesse trecho da narrativa de Valter Hugo Mãe. Se o estado emocional de Baltazar desvela angústia, o gesto de Teresa Diaba mostra a alegria do mundo dos prazeres; se a escalada na janela supõe cautela, discrição, para surpreender a possível traição, a queda exibe o segredo do ato. Assim, a ação de Baltazar, permeada de sofrimento, acaba por desvelar um viés cômico para o leitor que vê o intento findar de modo ridículo. Para a personagem, contudo, nada aconteceu de risível. Ao contrário, a suspeita do adultério, o ciúme, é móvel importante para maquinar a punição de Ermesinda, a despeito de ela estar lá por exigência de Dom Afonso, a quem ninguém ousa desrespeitar, nem mesmo Baltazar. Ermesinda representa o pharmakós, a vítima a ser castigada pelo fato de Baltazar e a família estarem circunscritos dentro de um sistema que não aceita senão a obediência cega aos senhores feudais. Ademais, o caráter do protagonista, o ciúme, carrega em si a tragicidade, mesmo em não colidindo com outra qualquer força.

As metáforas "frutos podres", "maçãs podres", que referenciam Ermesinda no texto, fazem alusão ao arquétipo feminino, que, segundo o ideário judaico cristão, referenda Eva como a desencadeadora dos males da humanidade, qual "fruto podre". Na sequência, surge uma comparação ("ficar com ele [pé] torcido duas vezes o da mãe"), que explicita que o protagonista tem um parâmetro de comportamento masculino que conflita com a sua jura de amor. Disse Baltazar no pedido de casamento: se "depender de mim será só digna sua pessoa, posta sobre meus braços como anjo que o céu me empresta".

$\mathrm{Na}$ narrativa são relatadas violências do pai à mãe de Baltazar com o propósito de educá-la. É a partir desse modelo de marido que o protagonista, ironicamente, pretende também educar a esposa, tanto que o castigo que assevera lhe infligir é o mesmo que seu pai já aplicara à sua mãe. $\mathrm{O}$ desconhecimento do teor da relação entre Dom Afonso e Ermesinda gera o ciúme, que, segundo a afirmação de Szondi, em análise de Othello, esse sentimento "é amor que destrói querendo proteger" (2004, p. 103). Depreende-se que nesse jogo de paradoxos - amar e proteger - se introduz o derruimento como força que contribui para gestar o trágico, quer em o remorso de baltazar serapião, quer em Othello.

Os próximos fragmentos expõem que nas ações da personagem a polaridade se reveste de um pretenso projeto de amor e de educação da esposa. Vejamos o primeiro. Baltazar apresenta-nos a noite de núpcias em que ele é guiado pelos ensinamentos do senhor Santiago, o curandeiro, que dias antes viera iniciá-lo ao matrimônio. Esta personagem exerce, na narrativa, o papel daquele que cuida do corpo e da alma das personagens. disse a ermesinda que se estendesse nua na cama. que eu a queria ver à luz da vela, muito próxima de cada pedaço da sua pele. ela pareceu acalmar quando the pus a mão suave no contorno da anca. Lembrei-me, toca-lhe com leveza, tal fosse coisa de partir da casa de dom afonso. porcelana da coleção da dona catarina. toca-lhe por amor. e assim fiz, segundo as palavras do senhor santiago (2010, p. 43-44).

Diante de Ermesinda nua, Baltazar lembra-se das recomendações do curandeiro e, neste ponto, o discurso indireto da personagem narrador altera-se para o discurso indireto livre. Esta mudança de voz resulta em ações marcadas sob o ponto de vista do outro, embora este enfoque seja absorvido pelo protagonista que o cumpre cabalmente. Cada passo desse ritual amoroso está vinculado a um modo de agir e a uma metáfora criada pelo discurso do senhor Santiago. Assim, temos "toca-lhe com leveza, tal fosse coisa de partir da casa de dom afonso" e, depois, "porcelana da coleção da dona catarina. toca-lhe por amor". O curandeiro, ciente da nenhuma experiência de Baltazar no trato com uma donzela, preocupa-se em introduzi-lo no mundo da ternura, do cuidado amoroso. Mais ainda: ele traduz esse comportamento em imagens do universo cultural do jovem para que ele aprenda bem a lição. "coisa de partir da casa de dom afonso" e "porcelana da coleção da dona catarina" são referências muito conhecidas da personagem. Por esse modo de ensinar, Baltazar estabelece a contiguidade entre Ermesinda e os objetos de seus senhores; ele reconhece que o mesmo zelo e suavidade de toque, que tem que dedicar a estes, em igual medida ele deve proceder com a esposa.

O fragmento escolhido para estabelecer relação com o anterior põe à vista a cena da chegada de Ermesinda em sua casa, depois de ter ficado retida na casa grande por ordem de Dom Afonso, conforme já nos referimos.

e, quando a ermesinda veio, [...] preparada para se explicar, sabia eu, e surpresa com a minha aparição gaguejou algo que não ouvi, tão grande foi o ruído de minha mão na sua cara e tão rápido lhe entornei o corpo ao contrário e lhe dobrei o pé esquerdo em todos os sentidos. que te saiam os peitos pela boca se me voltas a encornar, definharás sempre mais a cada crime, até que sejas massa disforme e sem diferença das pedras e das merdas acumuladas, [...]. e assim ficou revirada no chão, esfregada de dores corpo todo, a respeitar-me infinitamente para se salvar de morrer, e como me deitei fiquei, surdo de ouvido e coração, que o amor era coisa de muito ensinamento (2010, p. 53).

Cumpre primeiro observar que Baltazar sabe que Ermesinda irá se justificar, muito embora ele conheça as razões da demora da esposa. Por isso planeja agir antes que ela pronuncie a primeira palavra. Esta medida de silenciamento da voz feminina faz remissão ao primeiro 
parágrafo da narrativa, que funciona a modo de epítome, como mencionamos. Lá vimos que a voz feminina é considerada pelo protagonista como "perigosa e burra" (MÃE, 2010, p. 11) porque engana o homem e o destrói. Baltazar não quer que o discurso da esposa o seduza e o desvie de sua intenção. Pensando assim pratica violências contra Ermesinda, silencia-a, mutila-a. Depois do castigo aplicado, permanece "surdo de ouvido e coração". Este enunciado reafirma a decisão tanto de silenciamento quanto de negação da razão e de sobreposição do amor à situação em questão. Que cotejo poderíamos fazer entre o fragmento acima e o anterior?

Por primeiro analisemos a questão do silenciamento. O contexto ficcional é uma representação do sistema medieval. Neste, segundo Le Goff e Truong (2006), a mulher era vista como complemento da relação sexual, submetia-se à vontade do marido em todas as circunstâncias. A mesma sujeição encontra-se em Ermesinda. Ela se apresenta passiva, silenciada, enquanto Baltazar é ativo; só dele conhecemos as reações, os sentimentos. A jovem esposa reproduz a imagem de dependência feminina construída pela cultura. Do exposto se conclui que, seja em uma situação de suposto prazer, seja de crise, sempre a voz de Ermesinda é sufocada.

Observemos agora o tratamento que Baltazar dispensa ao corpo de Ermesinda nos dois extratos. No primeiro, Baltazar é orientado pela voz do outro para que aja com ternura e delicadeza. No segundo, age pelo ciúme, pela pulsão animal; rejeita a ponderação, ou recusa deixar-se levar pelo sentimento amoroso. $\mathrm{O}$ que se depreende desse comportamento conflitante é que Baltazar age de acordo com os dois modelos de atuação masculina no trato com a mulher: o paradigma paterno que lhe ensina cometer atrocidades e o do curandeiro Santiago, que concebe a mulher como um ser a quem se deve dedicar extremo desvelo. Poder-se-ia perguntar como Baltazar se vê? A imagem que a personagem tem de si é herdada da sociedade feudal que concebe o adultério feminino como uma desonra para o homem; por isso cobra da esposa a lealdade conjugal, a retidão. Entretanto, ao longo de toda a narrativa, por mais que busque provas de qualquer infidelidade, ele não encontra. Esta ausência da materialidade da transgressão produz efeito contrário ao esperado, em vez de eliminar a suspeita de culpa de Ermesinda, faz com que a dúvida dele mais recrudesça.

O ciúme gesta-se em si mesmo. Ele resulta da imagem que o sujeito tem de si. Em Othello (1996), por exemplo, é a personagem Brabâncio, no início da peça, quem faz insinuações a Otelo de que Desdêmona poderá traí-lo, depois Iago, sobretudo, encarrega-se de alimentar a semente do ciúme, refratando a imagem de Otelo que lhe convém, ou seja, aponta a inferioridade dele em relação a Cássio, o suposto adúltero. Enquanto este é jovem, belo, um cavalheiro que domina a arte do galanteio, da conversa nos salões, Otelo se reconhece estar velho, ter um discurso rude, que só sabe contar histórias das suas vitórias nas batalhas a serviço do estado ${ }^{3}$ (SHAKESPEARE, 1996, p.65). Esses sentimentos de inferioridade somam-se ao da exclusão, pelo fato de Otelo não ser um europeu. Deste quadro psicológico, podemos dizer que a baixa autoestima é condimento vital para gerar o ciúme. O mesmo sucede no romance português. Segundo a fala de Ermesinda e do próprio Dom Afonso, ela é tratada por este como "donzela de casta" (2010, p. 62), enquanto Baltazar reconhece a si e a sua família "aparentados de nossa vaca" (2010, p. 11). Seu comportamento e sua fala inserem o grotesco ${ }^{4}$ na narrativa: ele sai do discurso elevado que vimos no fragmento anterior e desce à terra, ao baixo corporal; ele deixa de ser o amador que cultua o belo, o cavalheirismo, o amor e passa a ser e a proceder como a espécie de seu suposto parentesco. Esta condição de animalização é relevante para a construção identitária de Baltazar e pode, de algum modo, ser também condimento para o ciúme, como podemos ver no fragmento seguinte:

[...] e dom afonso ordenou, sarga prepara teus filhos, que o talento e tempo do mais novo será oferta para sua majestade, $[\ldots]$.

e eu [Baltazar] entrei em casa e chorei tal pedido, que nos elevaria muito acima da nossa condição, e abracei o aldegundes amando-o. [...] lá [na corte, eu] o [aldegundes] deixaria em aposentos melhorados para cumprir o que tivesse até mo mandassem de recado a buscar novamente, quem sabe se para partirmos para novo lugar, para nova casa ou novo trabalho, conseguidos de maior riqueza para sairmos da condenação animal a que estávamos acometidos (2010, p. 106-107).

A passagem transcrita mostra que sair das terras de Dom Afonso significa para o protagonista dar novo rumo à sua vida. Por um lado, escapa da filiação da vaca Sarga, referência que o rebaixa dentro da comunidade, reduz a sua autoestima e questiona a sua identidade. Por outro lado, sinaliza para a liberdade da opressão que sofre sob os

\footnotetext{
3 O texto referido é o que se segue, no texto original: Othello - [...] Rude am I in my speech,/ And little blessed with the soft phrase of peace; For since these arms of mine had seven years' pith,/ Till now some nine moons wasted, they have used/ Their dearest action in the tented field; And little of this great world can I speak,/ More than pertains to feats of broil and battle; [...]" (Act I, Scene 3, v. 81-87). Tradução: Sou rude em minha fala,/ E pouco abençoado com frases suaves de paz;/ Pois desde que estes braços alcançaram o vigor dos sete anos, / Até agora, exceto as últimas nove luas, em nada eles foram eles foram empregados/Com mais amor do que em ações nos campos militares;/ Assim pouco posso contar sobre este vasto mundo,/ A não ser sobre o que se refere a feitos de luta e de combate. Tradução nossa.

$4 \mathrm{O}$ vocábulo grotesco é tomado aqui no sentido concebido por Mikhail Bakhtin (2002, p. 17) que o compreende como "a transferência ao plano material e corporal [...] de tudo que é elevado, espiritual, ideal e abstrato".
} 
domínios do senhor feudal e do assédio deste a Ermesinda. Baltazar é prisioneiro de uma vida extremamente pobre, mas acredita poder ser feliz, escapar da condição de vassalo, ao partilhar do possível reconhecimento da arte de seu irmão. Ele se aproxima do que Northop Frye (1973), na sua classificação dos heróis trágicos, concebe como herói dentro do modo imitativo baixo, porque Baltazar se ilude de que pode viver à parte da arbitrariedade do mundo feudal em que está inscrito, mudar a sua vida e o seu caráter de homem ciumento. Segundo Frye, "o pathos apresenta o herói como isolado por uma fraqueza que fala à nossa simpatia porque se situa em nosso plano de experiência" (1973, p.44). No caso de Baltazar a fraqueza é o ciúme. Acerca desse sentimento, podemos ainda considerar a réplica de Iago a Otelo, ao descrever o ciúme como "um monstro de olhos verdes, que debocha da carne de que se alimenta"5 (SHAKESPEARE, 1996, p. 110), ou seja, essa paixão pode em momentos parecer estar sob controle ou extinta, no entanto, ela apenas repousa para posteriormente eclodir na primeira dúvida que surge. $\mathrm{O}$ ciumento não consegue fugir de si mesmo. Ainda no que concerne à questão identitária, Baltazar mostra-se cindido. Os seus atos aproximam-no do mundo animal a que a comunidade vincula o seu nascimento, mas o seu amor e o seu propósito de viver feliz concedemlhe humanidade. Esta polaridade que vivencia é que the confere a dimensão trágica na narrativa.

As citações examinadas exibem variações de estados emocionais e de ações do protagonista representadas, em um primeiro momento, pelas antíteses na narrativa. No entanto, ao longo desta, a oposição não se plasma apenas como confrontação de elementos opostos que se alternam, mas como um comportamento que encerra em si uma antinomia, isto é, Baltazar diz querer bem à esposa e ao mesmo tempo lhe impõe castigo; ama e, ao mesmo tempo, ameaça, silencia, aterroriza. Essa dialética, nutrida pelo ciúme, tece na narrativa um grande oximoro. Analisemos agora o contraponto na narrativa criado pela presença desse recurso da retórica. O oximoro atua como mecanismo que agudiza ainda mais a tensão e aponta para a impossibilidade de conciliação entre os opostos uma vez que a antinomia é intrínseca a essa figura.

dias calados se fizeram. muito mais porque dom afonso, assustado com escândalo que lhe aumentasse, abdicara das visitas, a desoras de dona catarina, por parte da minha ermesinda. [...] por isso nada fiz que se pusesse às avessas dessa paz, senão puxar as rédeas da minha mulher que se arrastava em dores entre os

\footnotetext{
"O, beware, my lord, of jealousy!/ It is the green-eyed monster which doth mock/ The meat it feeds on. [...]" (Act III, Scene 3, v.165-167). Tradução nossa: "Oh, meu senhor, cuidado com o ciúme!/ Ele é um monstro de olhos verdes, que debocha da carne de que se alimenta". Tradução nossa.
}

queijos [em que trabalhava] e a casa, e perdera a língua de dizer coisas [...]. e em dias desses eu estive muito atento a amá-la muito mais por sabê-la a retomar o seu lugar, estropiada do pé mas bela de sempre, rosto e figura feminina por que me apaixonei, era sem dúvida a minha ermesinda, a minha doce mulher $(2010$, p. 54$)$.

A passagem transcrita surge depois do episódio em que Baltazar é flagrado pendurado na janela com a intenção de olhar o que acontece no interior do salão da casa grande entre Ermesinda e Dom Afonso. Curiosamente, o enunciado "nada fiz que se pusesse às avessas dessa paz, senão puxar as rédeas da minha mulher que se arrastava em dores entre os queijos e a casa, e perdera a língua de dizer coisas" inicia com uma denegação de ação que se apresenta como uma pressuposta contribuição da personagem para a manutenção da paz, seguida da exposição da ação que desvela violência, ato que contradiz o que foi previamente declarado. Pouco depois, a linguagem adensa ainda mais a oposição por meio do oximoro. Em seu discurso, a personagemnarrador contrapõe: "estive muito atento a amá-la" a "por sabê-la a retomar o seu lugar", o que implica um amor orientado pela opressão; a seguir confronta: "estropiada do pé" que exibe uma aparência de ser desfigurado pela barbárie de sua conduta para, a seguir, diluir essa imagem na parte seguinte do sintagma, cujo eixo repousa na atemporalidade da beleza de Ermesinda ("bela de sempre, rosto e figura feminina por que me apaixonei”). Para Baltazar, a mutilação em nada diminui esse predicado da esposa, assim como a sua relação amistosa, cordial, para com ela é contraditoriamente impregnada de tirania.

\section{Considerações finais}

Em suma, podemos dizer que tanto a antítese quanto o oximoro entretecem os fios discursivos para a construção da tensão da narrativa. A trajetória da personagem erige-se a partir do tempo da enunciação, quando a personagemnarrador apresenta o contexto cultural que rege a narrativa e o ethos que a enforma. Nela são exibidas as formações discursivas do mundo medieval que disforiza a mulher, silencia-a, nega-lhe a identidade. Como agravante desse contexto cultural, existe a arbitrariedade do senhor feudal, em torno do qual gravitam as personagens.

Nesse mundo de dominação, o protagonista não encontra liberdade de escolhas. Seu destino é construído em uma rede de opressão e de aniquilação física e moral, quer ditada pelo sistema feudal, quer pelo patriarcado. Dentro desse universo sociocultural, parece pouco adequada a classificação de Baltazar, como herói, se levar em conta as raízes épicas do romance. No entanto, Northrop Frye, em Anatomia da crítica (1973), oferece-nos uma possibilidade de classificar o protagonista 
como herói no modo trágico imitativo baixo. Baltazar representa o homem comum que vive entre a tirania de Dom Afonso e a violência gerada pelo ciúme que ele aplica à sua esposa, na intenção de protegê-la. Sua heroicidade fica comprometida por ele denegar o sistema que o oprime e, ao mesmo tempo, produzir a violência. Este paroxismo é criado pelo ciúme que responde pela "queda", para usarmos a terminologia de Albin Lesky (1971, p. 26), ao considerar esse requisito como um dos traços que compõe o estatuto do herói trágico. Em $o$ remorso de baltazar serapião (2010), pode-se dizer que a segurança no amor que prenuncia felicidade no início da narrativa rapidamente mostra-se ilusória e sucumbe às desgraças sobrevenientes. Inscrito numa sociedade em que exerce os papéis de opressor e de oprimido, destituído de sua identidade, impotente para reverter o seu destino, a personagem resvala, aniquilada, para o desfecho trágico. Essa amálgama de grandeza e pequenez humanas comove o leitor, que encontra na personagem a humanidade que a sobreleva e, ao mesmo tempo, a brutalidade que a rebaixa e a destrói. Ao final, o leitor é surpreendido pela inação de Baltazar diante do estupro de Ermesinda praticado por seu irmão e seu amigo.

[...] eu sentiria até ali o remorso dos bons homens. como havia pensado, remorso duro de tão dignamente administrar a educação da minha ermesinda. mas até ali, pensei, até ali, porque naquele momento, [...] ocorreu-me a falha grave do meu espírito, e tão amargamente me foi claro que, por piedade ou compreensão com meus companheiros, e talvez por ausência da voz da minha mulher, passara para lá do limite. o remorso dos bons homens já não me assistia, senão a burrice e ignorância de quem abdicara da sua mulher" (2010, p. 193-194).

Pode-se dizer que o conflito maior de Baltazar não é contra o mundo exterior, mas dentro de si, por sentir-se prisioneiro dos seus limites, de suas fraquezas humanas. Durante a narrativa, obsessivamente ele busca em vão uma prova da infidelidade. A ironia trágica estabelece-se no momento em que urge defender sua esposa do estupro, mas fica entorpecido. Baltazar acompanha essa cena final em suspensão até o final trágico de Ermesinda. O remorso mencionado no título do romance não se atualiza nos sentimentos do herói no desfecho da narrativa, como se explicita no jogo entre o tempo anterior à enunciação - o tempo dos acontecimentos - e o tempo dela; entre o que "até ali" "havia pensado" e, o que, mediante o exercício rememorativo, "tão amargamente [lhe] foi claro". Seu estado agônico prende-se aos polos de tensão: o possível redirecionamento do sentimento amoroso a Ermesinda para o campo de ressignificação da imagem dela e a visão machista que reduz a significância da mulher em favor do sentimento de solidariedade ao homem (seus companheiros). Seria necessário que Baltazar tivesse dado um passo a mais na direção do respeito à pessoa de Ermesinda e do amor que ele sempre afirmara dedicar a ela para que a lucidez lhe exibisse o desvalimento de sua esposa (em decorrência dos maus tratos que ele lhe infligira) e a violência do estupro. No entanto, sua paralisação diante dessa cena soma-se ao peso secular de tantos outros gestos do mundo machista. No confronto entre o amor e, por extensão, a defesa de Ermesinda que o humanizariam e a força do sistema patriarcal que reifica a mulher e o ata ao mundo da barbárie, vence esta última.

\section{Referências}

ARISTÓTELES. Poética. Tradução e notas Ana Maria Valente. 2. ed. Lisboa: Fundação Calouste Gulbenkian, 2007.

BAKHTIN, Mikhail. A cultura popular no Renascimento e na Idade Média: o contexto de François Rabelais. Tradução Yara Frateschi Vieira. São Paulo: Hucitec, 2002.

CAMÕES, Luís de. De quantas graças tinha, a Natureza. In: Obra completa. Rio de Janeiro: Aguilar, 1963.

FRYE, Northrop. Anatomia da crítica. Tradução Péricles Eugênio da Silva Ramos. São Paulo: Cultrix, 1973.

LESKY, Albin. A tragédia grega. Tradução J. Guinsburg, Geraldo Gerson de Souza e Alberto Guzik. São Paulo: Perspectiva, 1971.

MÃE, Valter Hugo. o remorso de baltazar serapião. São Paulo: Editora 34, 2010.

NUNES, Maria Leonor. As grandes minúsculas de Valter Hugo Mãe. In: Jornal de Letras, Artes e Ideias. 24 de janeiro de 2010. Disponível em: <http://visao.sapo.pt/as-grandes-minusculasde-valter-hugo-mae=f545016> . Acesso em: 02 abr. 2017.

SHAKESPEARE, William (ca. 1604). Othello. London: Penguin Books, 1996.

SZONDI. Peter. Ensaio sobre o trágico. Tradução Pedro Süssekind. Rio de Janeiro: Jorge Zahar Editor, 2004.

Recebido: $18 / 04 / 2017$

Aprovado: 11/01/2019

Autora:

Aurora Gedra Ruiz Alvarez

Universidade Presbiteriana Mackenzie. São Paulo, SP, Brasil. auroragedra@hotmail.com 